\title{
The headstarting technique is an ineffective method for conservation of the European pond turtle - elasticity analysis
}

\author{
Slawomir Mitrus \\ Laboratory of Vertebrate Zoology, Department of Biosystematics, Opole University, \\ Oleska 22, 45-052 Opole, Poland \\ e-mail: emyspl@yahoo.com
}

\begin{abstract}
The European pond turtle (Emys orbicularis) is endangered in many areas within its distribution range. Thus, protection programmes for the turtle populations are in place. However, the efficiency of some techniques (including a highly manipulative one headstarting) is questionable. Elasticity analysis was conducted using the life history data gathered in central Poland during the period 1986-2002. The analysis revealed that headstarting is a fairly ineffective method. The most effective methods are those that protect adult individuals. Thus, methods that can sustain a decreasing adult mortality rate should be recommended for turtle conservation.
\end{abstract}

Key words: Emys orbicularis, freshwater turtle, active protection, management.

\section{Introduction}

Populations of the European pond turtle Emys orbicularis (L.) are considered endangered in several parts of its distribution range (Fritz \& Andreas 2000). Thus, several European countries (e.g. Germany, Lithuania, Italy, Spain and Poland), have initiated protection programmes (including headstarting - and other highly manipulative ones) for this species (cf. Mitrus 2005). The headstarting technique involves raising turtle hatchlings in captivity with age ranges of a few months up to several years, and then releasing them into a natural habitat. The aim of headstarting programmes is to reduce hatchling mortality (Heppell et al. 1996; Flanagan 2000; Meylan \& Ehrenfeld 2000). Recent analyses imply that for freshwater turtles, such a technique is an inefficient tool for increasing the population growth (e.g. Heppell et al. 1996; Heppell 1998); however, such programmes are still being carried out.

For any species conservation, it is important to know which technique could be the most effective. Elasticity analysis allows one to compare the proportional effects of changes in parameters that are not on the same scale (e.g. survival: $0-1$, and fecundity often much more than 1 ), and for stages with different time scales (e.g. an adult freshwater turtle lives several dozen years; Heppell et al. 1996; Heppell 1998). This kind of analysis indicates which life history parameters are critical to population growth, and as such help to focus conservation activities on definite stages. The objective of this study was to use elasticity analysis to assess demographic data of the European pond turtle, in order to check if headstarting programmes could be effective.

\section{Methods}

In the analysis I used data for the European pond turtle population gathered in the Borowiec Nature Reserve. The reserve is situated in the Zwolenka River valley in central Poland (the Radom District; the location presented in Mitrus \& Zemanek 2004; more details about the reserve can be found in Zemanek 1992). Studies on the turtle in this area have been carried out since 1986, and a headstarting programme has been in place since 1989. Intensive 
fieldwork was conducted from 1997 to 2001, and clutches deposited in 2001 were followed till spring 2002 (for detail of the fieldwork see: Mitrus \& Zemanek 2004; Mitrus 2005).

The long life and secretive behaviour of the turtle make the collection of all life history data for any population very difficult. There is no information for the Reserve's population about the life span of the turtle and the survival rate of turtles age 2 . I have assumed the parameters to be 100 years and 0.8 respectively; assumptions based on the literature data for other freshwater turtle species. For example, in the life tables for the snapping turtle Chelydra serpentina (L.) and Blanding's turtle Emydoidea blandingi (Holbrook 1838), the life span is assumed to be 110 years (Congdon et al. 1993, 2000). In natural conditions individuals of the Blanding's turtle have been observed (a species closely related to Emys orbicularis; Feldman $\&$ Parham 2002), which live more than 65 years (Pappas et al. 2000; Congdon et al. 2001, 2003). Thus, it is possible that individual European pond turtles could live up to about 100 years.

For the annual survival rate of turtles age 2 years, I assumed $0.80-$ the same as the one found for turtles aged between 3-9 (Mitrus \& Zemanek 2004), because for other freshwater turtle species, the survival rate of individuals age 2 and older was similar (e.g. Gibbons \& Greene 1990; Congdon et al. 1993, 1994). There is also no information about the sex ratio of hatchlings. The assumed parameter is $1: 1$.

In elasticity analysis, I used a life table for the European pond turtle framed as an age-based Leslie Matrix (cf. Heppell et al. 1996). I calculated the initial population vector from the stable-age distribution of the life table (the applied parameters are presented in Tab. 1). Then, I calculated the proportional change in $\lambda$ (the population multiplication rate) given a proportional change in the stage specific annual survival rate or fecundity as:

$$
\text { elasticity }(x)=\left(\lambda_{(x+0.01 x)}-\lambda_{(x-0.01 x)}\right) /\left(\lambda_{x} \times 0.02\right),
$$

where: $x$ is the analysed stage or fecundity, and $\lambda_{(x+0.01 x)}$, $\lambda_{(x-0.01 x)}$ is the deterministic growth rate of the model with parameter $x$ increased or decreased by 1\% (cf. Heppell et al. 1996).

If the localities of nests are known, they could be protected (e.g. using the method described in Graham 1997). Hatchlings are typically kept in artificial rearing during headstarting programs (typically young turtles are kept in artificial conditions for several months). Thus, I calculated the elasticities for the survival rate of nests and hatchlings,

Table 1. The data used in elasticity analysis for the European pond turtle Emys orbicularis. The data are based on field data gathered in central Poland. The population growth rate: $\lambda=1.010$

\begin{tabular}{|l|l|l|}
\hline \multicolumn{1}{|c|}{ Stage / parameter } & \multicolumn{1}{|c|}{ Annual survivorship } & \multicolumn{1}{c|}{ Data source } \\
\hline Eggs/hatchlings & $\begin{array}{l}0.075 \\
\text { (within: survival of nests } \\
\text { during spring and summer: } 0.8)\end{array}$ & Mitrus 2005 \\
\hline Age 1 year & 0.525 & $\begin{array}{l}\text { based on the data for 25 one-year-old turtles (for details see: Mitrus } \\
\text { 2002) }\end{array}$ \\
\hline Age 2 years & 0.80 & $\begin{array}{l}\text { assumed, see text (during the field studies all three observed two- } \\
\text { year-old turtles survived from 1999 to 2000 - their survival rate }= \\
1,0 ; \text { Mitrus 2002) }\end{array}$ \\
\hline Age 3-9 years & 0.80 & Mitrus \& Zemanek 2004 \\
\hline Age 10 years and more & 0.98 & Mitrus \& Zemanek 2004 \\
\hline Fecundity & & $\begin{array}{l}\text { based on 47 clutches of 24 different females, data for years } \\
1998-2001 \text { (for details see: Mitrus 2002) }\end{array}$ \\
\hline Clutch frequency & $0.84 /$ year & $\begin{array}{l}\text { based on data from four seasons 1998-2001 (for details see: Mitrus } \\
\text { 2002) }\end{array}$ \\
\hline Female age of maturity & 15 years & Mitrus \& Zemanek 2004 \\
\hline Hatching sex ratio & $1: 1$ & assumed, no data available \\
\hline Maximum life span & 100 years & \begin{tabular}{l} 
assumed, see text \\
\hline
\end{tabular} \\
\hline
\end{tabular}




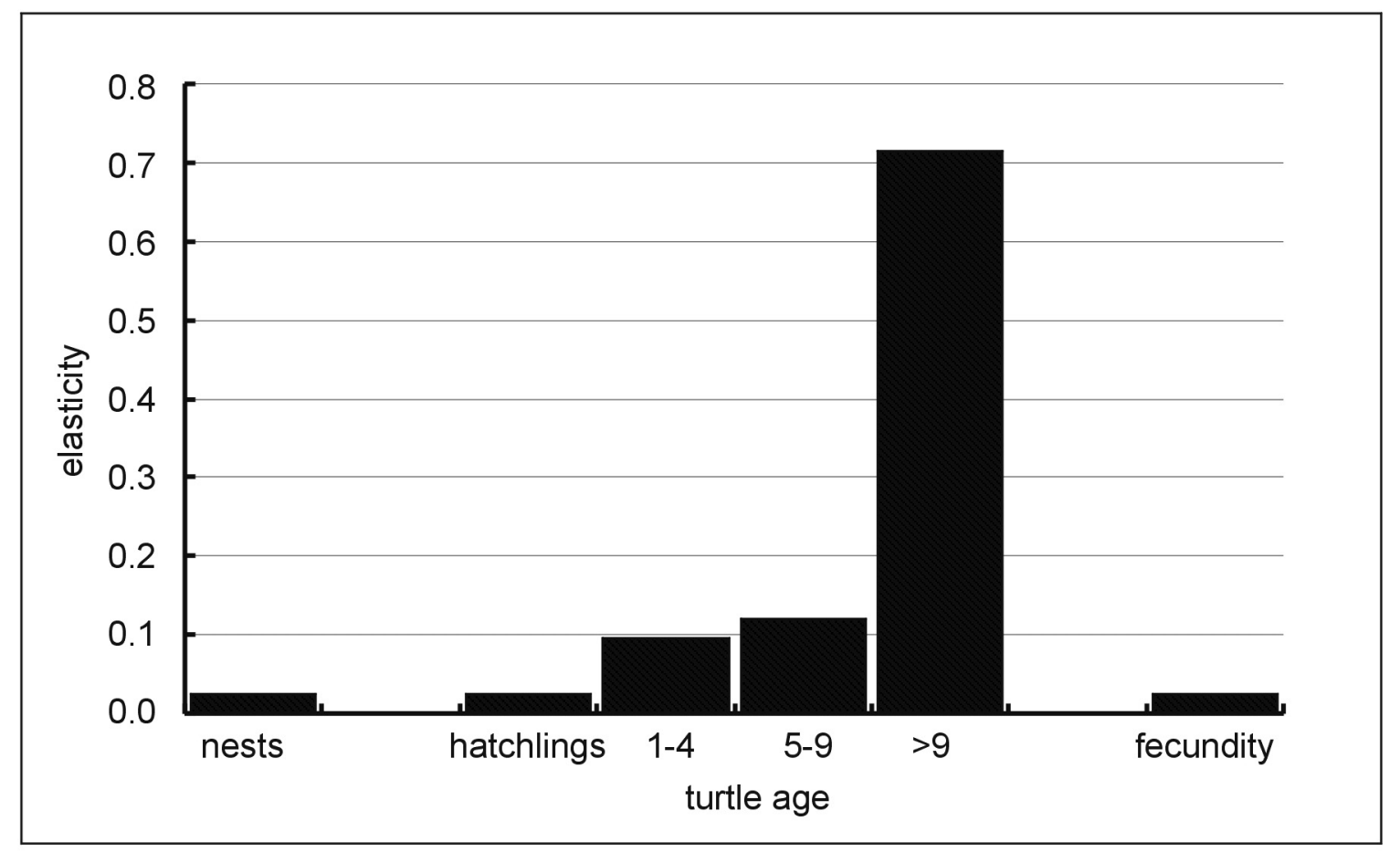

Figure 1. Elasticities of stage specific classes and fecundity of the turtle Emys orbicularis from central Poland. Elasticity = proportional contribution of the annual survival rate of any class or fecundity to $\lambda$ (the proportional multiplication rate)

but also for young turtles (1-4 years old), subadults $(5-9$ years old), and adults (individuals more than nine-yearsold, including females close to maturity).

\section{Results}

The analysis indicates which stage-specific vital rates are the most critical to the overall population growth rate for the European pond turtle. The adult turtle survival rate has the greatest influence on the population multiplication rate (Fig. 1). For young turtles (1-4 years old), and subadults (5-9 years old) elasticities are similar, however they are lower than for adult individuals. For hatchlings, the nest survival rate and the fecundity of females' elasticities are low. Thus the turtle population dynamics is more strongly driven by survival rates of adult individuals than by fecundity or the survivor rate of nests and younger turtles.

\section{Discussion}

The elasticity analysis for the European pond turtle was based primarily on the field data. Some parameters were assumed, but generally for different freshwater turtle species, the life history parameters are similar (Wilbur \& Morin 1988).

The highest elasticites for the annual survival rate of adults show that proportional changes in the survival rate of such animals have the biggest influence on the population dynamics (Fig. 1). The results of the elasticity analysis revealed that for the European pond turtle, the most effective protection is reserved for adult individuals. The protection of young turtles only (e.g. based on headstarting programmes) or/and nests will be ineffective. The data are similar to results for different species of freshwater turtles (Heppell 1998), and the results of modelling the dynamic population of the European pond turtle using deterministic matrix models (Mitrus 2005).

Based on the elasticity analysis only, it is obvious that protection programmes should be focused on adult turtles, although "naive interpretation of the elasticities should be avoided. Simple analytical elasticities are a useful, fairly robust first step in a wider framework of model building and hypothesis testing in evolutionary or demographic analysis" (Benton \& Grant 1999). It is important to remember that typically, it is possible to increase the survival rate of adults individuals less than the survival rate of young turtles, and that elasticities are calculated for proportional changes of any parameter. 
Elasticity analysis could help in the selection of a better protection method where there are some alternatives. However, additional factors should be taken into consideration, such as differences between the alternative programmes (e.g. how many times the survival rate could be increased for different stages), costs of different programmes, and others factors (e.g. there could be differences in the age of maturity and the long-term survival rates of wild and headstarted individuals, although these factors are currently unknown, Mitrus 2005).

For the sea turtles, headstarting programmes have been used since the $1950 \mathrm{~s}$, but for a long time there was no effective method of evaluating the effects of these programmes or the effects were minor (Seigel \& Dodd 2000). Later elasticity analyses showed that for the population dynamics of sea turtles, it is more important to protect subadult and juvenile individuals than hatchlings (Heppel et al 1996; Heppell 1998), and that headstarting programmes do not eliminate the main causes of mortality in most sea turtle populations; namely, the loss of turtles from drowning in shrimp nets and from overfishing (Meylan \& Ehrenfeld 2000). Thus, presently another method is used in the form of - turtle excluder devices, which are installed in nets. Such excluders contain a grid of bars with an opening to the trawl net. Small animals such as shrimps pass through the bars and are caught in the bag end of the trawl, but larger animals (e.g. sea turtles) are ejected through the opening. The positive effects of such a method of sea turtle protection is higher than for headstarting programmes (Frazer 1992; Lewison et al. 2003, 2004).

The high elasticity value of any parameters should focus the research on possible anthropogenic mortality sources in definite stages (Heppell 1998). For the European pond turtle the highest elesticities are for adult individuals. Thus, for the protection of the turtle populations the most important factor is the protection of adult individuals. However, for the majority of the European pond turtle populations there is no single identified reason for the high level of adult mortality and only some data are available on the adult survival rate of the turtle. At present, studies focused on the reasons for adult mortality are necessary, and new protection programmes for the turtle concentrated on adult individuals - should be recommended. Headstarting programmes and nest protection schemes could work only when they are used in tandem with adult individual protection programmes (Heppell 1998; Meylan \& Ehrenfeld 2000).

\section{Acknowledgements}

I wish to express my thanks to all my friends who helped in the field during this study, especially to Dr. M. Zemanek and Eng. A. Kotowicz. I also thank R. Tertil and Ian Har- man, both of Letterman, Translators \& Interpreters who provided linguistic corrections. Data used in the study were collected as part of an active protection programme for the European pond turtle supported by the Environment and Agriculture Department, Mazovia Province Office in Warsaw, EcoFund - Polish Debt for Environment Swap, Global Environment Facility - GEF/SGP UNDP, and Kozienice Landscape Park.

\section{References}

Benton T. G. \& Grant A., 1999, Elasticity analysis as an important tool in evolutionary and population ecology, Trends in Ecology and Evolution 14: 467-471.

Congdon J. D., Dunham A. E. \& van Loben Sels R. C., 1993, Delayed sexual maturity and demographics of Blanding's turtles (Emydoidea blandingii): implications for conservation and management of long-lived organisms, Conservation Biology 7: 826-833.

Congdon J. D., Dunham A. E. \& van Loben Sels R. C., 1994, Demographics of common snapping turtles (Chelydra serpentina): implications for conservation and management of long-lived organisms, American Zoologist 34: 397-408.

Congdon J. D., Nagle R. D., Kinney O. M., Osentoski M., Avery H. W., van Loben Sels R. C. \& Tinkle D. W., 2000, Nesting ecology and embryo mortality: implications for hatchling success and demography of Blanding's turtles (Emydoidea blandingii), Chelonian Conservation and Biology 3: 569-579.

Congdon J. D., Nagle R. D., Kinney O. M. \& van Loben Sels R. C. V., 2001, Hypotheses of ageing in a long-lived vertebrate, Blanding's turtle (Emydoidea blandingii), Experimental Gerontology 36: 813-827.

Congdon J. D., Nagle R. D., Osentoski M. R., Kinney O. M. \& van Loben Sels R. C., 2003, Life history and demographic aspects of aging in the long-lived turtle (Emydoidea blandingii), [in:] C. E. Finch, J.-M. Robine \& Y. Christen (eds.), Brain and longevity, Springer-Verlag, Berlin-Heidelberg: 15-31.

Feldman C. R. \& Parham J. F., 2002, Molecular phylogenetics of Emydine turtles: taxonomic revision and the evolution of shell kinesis, Molecular Phylogenetics and Evolution 22: 388-398.

Flanagan J., 2000, Disease and health consideration, [in:] M. W. Klemens (ed.), Turtle Conservation, Smithsonian Institution Press, Washington D.C.- London: 85-95.

Frazer N. B., 1992, Sea turtle conservation and halfway technology, Conservation Biology 6: 179-184.

Fritz U. \& Andreas B., 2000, Distribution, variety of forms and conservation of the European pond turtle, [in:] Proceedings of the 2nd International Symposium on Emys orbicularis, Chelonii 2: 23-26. 
Gibbons J. W. \& Greene J. L., 1990, Reproduction in the slider and other species of turtles, [in:] J. W. Gibbons (ed.), Life history and ecology of the slider turtle, Smithsonian Institution Press, Washington D.C.- London: $124-134$.

Graham T., 1997, Effective predator excluders for turtle nests, Herpetological Review 28: 76-76.

Heppell S. S., 1998, Application of life-history and population model analysis to turtle conservation, Copeia 1998: $367-375$.

Heppell S. S., Crowder L. B. \& Crouse D. T., 1996, Models to evaluate headstarting as a management tool for long-lived turtles, Ecological Applications 6: 556-565.

Lewison R. L., Crowder L. B. \& Shaver D. J., 2003, The impact of turtle excluder devices and fisheries closures on loggerhead and Kemp's ridley strandings in the western Gulf of Mexico, Conservation Biology 17: 1089-1097.

Lewison R. L., Crowder L. B., Read A. J. \& Freeman S. A., 2004, Understanding impacts of fisheries bycatch on marine megafauna, Trends in Ecology and Evolution 19: 598-604.

Meylan A. B. \& Ehrenfeld D., 2000, Conservation of marine turtle, [in:] M. W. Klemens (ed.), Turtle Conservation, Smithsonian Institution Press, Washington D.C.-London: 96-125.

Mitrus S., 2002, Historia życiowa żółwia błotnego, Emys orbicularis - implikacje dla ochrony gatunków długo żyjących [Life history of the European pond turtle, Emys orbicularis - implications for conservation of long-lived organisms], PhD Thesis, Uniwersytet Jagielloński, Kraków: 1-101.

Mitrus S., 2005, Headstarting in the European pond turtles - does it work?, Amphibia-Reptilia 26: 333-341.

Mitrus S. \& Zemanek M., 2004, Survivorship of the European pond turtle Emys orbicularis in central Poland, [in:] Proceedings of the 3rd International Symposium on Emys orbicularis, Košice, Slovak Republic 2002, Biologia: 103-107.

Pappas M. J., Brecke B. J. \& Congdon J. D., 2000, The Blanding's turtles (Emydoidea blandingii) of Weaver Dunes, Minnesota, Chelonian Conservation and Biology 3: $557-568$.

Seigel R. A. \& Dodd K. C. Jr., 2000, Manipulation of turtle populations for conservation: halfway technologies or viable options?, [in:] M. W. Klemens (ed.), Turtle Conservation, Smithsonian Institution Press, Washington D.C. - London: 218-238.

Wilbur H. M. \& Morin P. J., 1988, Life history evolution in turtles, [in:] C. Gans \& R. B. Huey (eds.), Biology of the Reptilia, A. R. Liss, New York: 391-440.

Zemanek M., 1992, Rezerwat przyrody Borowiec w dolinie Zwoleńki [Borowiec Nature Reserve in the Zwoleńka river valley], Ochrona Przyrody 50: 173-195. 